\title{
Studies on Mukwa (Pterocarpus angolensis, D. C.) Dieback in Chobe Forest Reserves in Botswana
}

\author{
Ronnie M. Mmolotsi ${ }^{1}$, Motshwari Obopile ${ }^{1}$, Baone C Kwerepe ${ }^{1}$, Boingotlo Sebolai ${ }^{2}$, Melusi P. Rampart ${ }^{1}$, \\ Amogelang T. Segwagwe ${ }^{1}$, Gaebewe Ramolemana ${ }^{3}$, Tlholego M. Maphane ${ }^{1}$, Lerato Lekorwe ${ }^{1}$, Ishmael Kopong ${ }^{1}$, \\ Moneedi Kelatlhilwe ${ }^{1} \&$ Bamphitlhi Tiroesele ${ }^{1}$ \\ ${ }^{1}$ Department of Crop Science and Production, Botswana College of Agriculture, Gaborone, Botswana \\ ${ }^{2}$ Department of Basic Science, Botswana College of Agriculture, Gaborone, Botswana \\ ${ }^{3}$ Centre of Continuing Education, University of Botswana, Gaborone, Botswana \\ Correspondence: Ronnie M. Mmolotsi, Department of Crop Science and Production, Botswana College of \\ Agriculture, Gaborone, Botswana. Tel: 267-3650-210. E-mail: rmmolots@bca.bw
}

Received: May 30, 2012 Accepted: July 2, 2012 Online Published: August 20, 2012

doi:10.5539/jps.v1n2p154 URL: http://dx.doi.org/10.5539/jps.v1n2p154

\begin{abstract}
A study was carried out in forest reserves located in Chobe district in Botswana to assess the effect of dieback and associated causes on Mukwa tree, Pterocarpus angolensis Fire, elephant damage and dieback were assessed in Chobe and Kazuma forest reserves and Pandamatenga farming area. Fire damage frequency on mukwa trees ranged between 60 to $100 \%$ and was highest in Pandamatenga and Chobe forest reserves. The frequency of elephant damage in Kazuma and Chobe forest reserves was 75 and $100 \%$ respectively. There was no elephant damage in Pandamatenga farms because the area is fenced out and minor dieback occurred in the area. All areas under study experienced $100 \%$ incidence of dieback, but the severity ranged from 22 to $100 \%$, the highest being at Chobe forest reserve and the lowest at Pandamatenga. Severity of dieback was associated with elephant damage and age of $P$. angolensis trees. The incidence of dieback was correlated with DBH and tree age. The results indicate that the cause of dieback is mostly due to elephant and fire damage.
\end{abstract}

Keywords: Pterocarpus angolensis, dieback, fire, elephant, Botswana

\section{Introduction}

Mukwa (Pterocarpus angolensis) is a nitrogen fixing indigenous tree belonging to the Papilionoideae family, which is widespread in woodland and wooded grassland throughout Central, East and Southern Africa (Banda, Schwartz, \& Caro, 2006). The tree grows throughout Northern Botswana and may be found in all woodland types as well as in dry evergreen and dry deciduous forests (Coates-Palgrave, 1992). P. angolensis is valuable in furniture making, flooring, musical instruments, and boats, charcoal making as well as being a source of firewood, tool handlings, carving, construction poles, medicine, fodder, bee forage and as an ornamental plant (Coates-Palgrave, 1992).

P. angolensis is one of the most well-known woods in southern tropical Africa (Banda et al., 2006) characterised by a durable heart wood which is resistant to fire, decay, wood rotting fungi, termite attack, terrestrial and marine borers (Coetzee \& Van Vuuren, 1984; Monela, O'Ktin'ati, \& Kiwele, 2003). The sapwood, however is susceptible to damage by powder post beetles and other borers implying that logs need to be converted into boards as soon as possible and planks pre-treated before air drying (Coetzee \& Van Vuuren, 1984). P. angolensis in the forest reserves is affected by elephant damage, fire, drought and dieback which may have impact on the species populations. The effects of dieback on natural populations of $P$. angolensis on the Miombo woodlands in general have been reported by several authors (Anon, 1985; Banda et al., 2006; Kikula, 1986; Rampart, 2007; Rampart, Cahalan, Mmolotsi, \& Kopong, 2010). The major factors causing dieback of $P$. angolensis include elephants (Ben-Shahar, 1993; Ben-Shahar, 1996; Rampart et al., 2010) and diseases (Mehl, Geldenhuys, Roux, \& Wingfield, 2010). P. angolensis has been reported to be on decline in the Chobe Forest Reserves due to dieback (unpublished reports). However, knowledge on the severity of dieback and the casual factors in the Chobe District Forest Reserves is lacking. The objective of this paper was therefore to assess incidence and severity of dieback on $P$. angolensis and identify causal agents. 


\section{Materials and Methods}

\subsection{Description of the Study Site}

The study was carried out in the Chobe District forest reserves in the northern part of Botswana. The area has an altitude of up to 1000 meters above sea level (Department of Metereological Services, 2004). The Chobe forest reserves are characterized by harder, poorly drained soils, mainly near pans (Remmelzwaal, van Wavern, \& Baert, 1988) and at some places slightly shallower and deep alluvial drier soils. The soils are generally neutral to acidic, poor in nutrients, with poor soil structure and low water holding capacity. The area is frequented by forest fire (Ben-Shahar, 1998). The climate of the area is sub-tropical with distinct summer and winter seasons. The Chobe forest reserves receive the highest annual rainfall in the country amounting to about $650 \mathrm{~mm}$ during the summer months between December and April. Temperatures vary between a mean monthly maximum of $34{ }^{\circ} \mathrm{C}$ and a mean minimum of $6^{\circ} \mathrm{C}$ (Bhalotra, 1985). The Chobe forest vegetation is dominated by Baeikea plurijuga, Pterocarpus angolensis, Kirkia acuminata, Schinziophyton rautanenii, Guibourtia coleosperma, Combretum spp, Brachystegia spp, Burkea africana, Terminelia sericea and Colophospermum mopane (Nowergian Forestry Society, 1992).

\subsection{Experimental Procedures}

A survey following a systematic sampling method was carried out in the two Forest Reserves namely Kazuma and Chobe Forest Reserves to assess the extent of dieback. Using a compass and measuring tape five transects of $1 \mathrm{~km}$ long each (i.e. $200 \mathrm{~m}$ inter transects spacing) were established at 50-100 m intervals from the initial reference point. Five plots $(25 \mathrm{~m} \times 25 \mathrm{~m})$ separated by $200 \mathrm{~m}$ along transects were marked and all the trees showing symptoms of dieback and disease attack were recorded and percentage of affected trees determined using the following formula.

\section{Average infection rate $(\%)=\Sigma\left(\frac{\text { of tress offected bydtebaekperplet }}{\sum \text { of thetresperplot }}\right) / \mathrm{N} * 100$}

Where $\mathrm{N}=$ number of sampling units per forest reserve.

Pest and disease assessment was done on felled trees, by cutting open the stem to investigate infestation. The sampled arthropods were then taken to the Botswana College of Agriculture Entomology laboratory for identification Samples of plants showing signs of infection were collected and brought to the laboratory for identification of pathogens. Soil and root samples were collected from the bases of the stems of felled trees to assess and assayed for soil borne microorganisms such as nematodes, fungi and bacteria. These microorganisms were isolated from infected trees and cultured on various nutrient media in the laboratory and then identified.

\section{Results and Discussion}

\subsection{Dieback, Fire and Elephant Damage}

Fire and elephant damage and dieback severity are shown in Table 1. P. angolensis in the Pandamatenga farming area, showed the least number of damage trees. The highest fire and elephant damage was observed in the Chobe Forest Reserve which also showed the highest diameter range with aging trees. Mehl et al. (2010) reported that the occurrence of dieback was related to fire damage. McGregor and O'Connor (2002) reported that dieback may also be influenced by vegetation structure, soil surface structure and soil chemistry. Natural thinning due to competition in dense forests has also been reported to result in dieback (McGregor \& O'Connor, 2002).

Table 1. Fire, elephant damage and dieback in the different forest reserves

\begin{tabular}{lllllll}
\hline Reserve & $\begin{array}{l}\text { Fire } \\
\text { damage } \\
(\%)\end{array}$ & $\begin{array}{l}\text { Elephant } \\
\text { damage } \\
(\%)\end{array}$ & $\begin{array}{l}\text { Dieback } \\
\text { frequency } \\
(\%)\end{array}$ & $\begin{array}{l}\text { Dieback } \\
\text { severity } \\
(\%)\end{array}$ & $\begin{array}{l}\text { DBH } \\
(\mathrm{cm})\end{array}$ & $\begin{array}{l}\text { Height } \\
(\mathrm{m})\end{array}$ \\
\hline Chobe & 100 & 100 & 100 & 100 & $96.73 \pm 1.5$ & $17.27 \pm 0.8$ \\
Kazuma & 60 & 75 & 100 & 22.2 & $40.49 \pm 2.9$ & $13.25 \pm 0.4$ \\
Pandamatenga & 100 & 0 & 100 & 10 & $41.72 \pm 2.3$ & $14.26 \pm 0.5$ \\
P value & & & & & 0.006 & 0.0013 \\
\hline
\end{tabular}




\subsection{Insect Pests}

The main insect pest observed on trees in the forest reserves were termites and wood boring insects. The species of termites found were in the families, Termitidae (Apicotermitinae, Termitinae, Macrotermitinae) and Hodotermitidae. The wood boring insects observed were in the family, Cerambycidae, order Coleoptera. Other insects associated with dieback like scale insects were not found on trees sampled from the forest reserves during the study. The termites were mostly found damaging the pith and heartwood of mukwa trees producing hollow openings in the stem (Figure 1). However there was no evident connection between pith damage by termites and dieback. The tunnelling done by cerambyicid larvae also could not be evidently associated with dieback. Dieback in P. angolensis was reported to be caused by scale insects (Aspidoproctus glaber) (Patterson, Saint-Cyr, \& Russell, 2007).
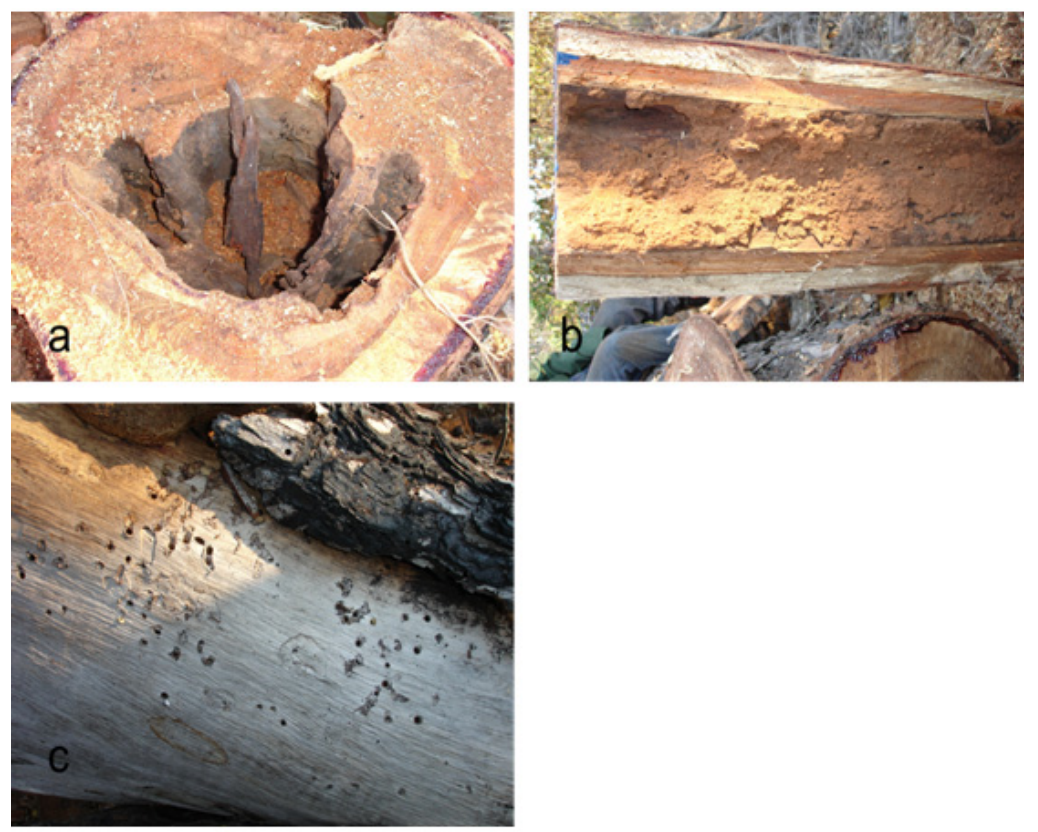

Figure 1. Damage by termites ( $a$ and $b$ ) through tunnelling and Cerambycidae (c) tunneling in the sapwood

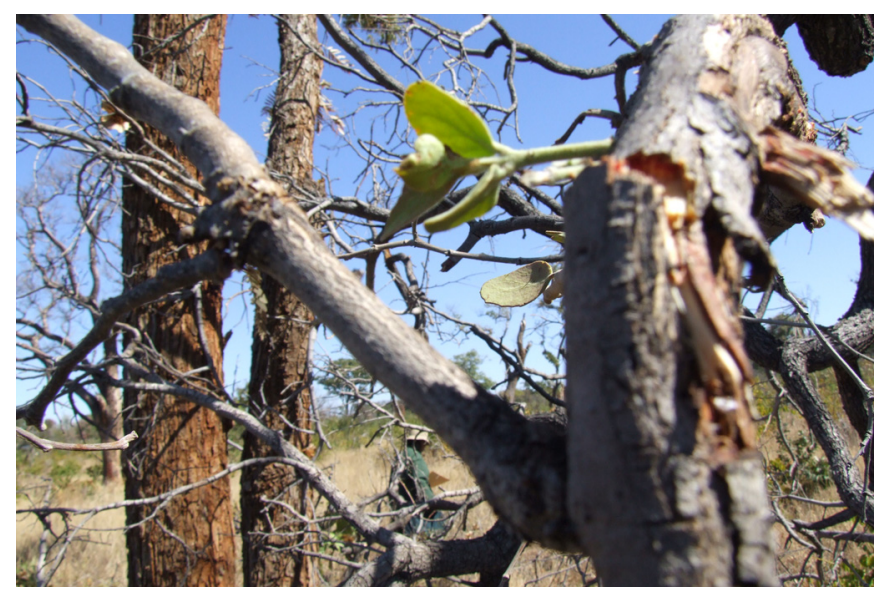

Figure 2. Mistletoe growing on mukwa trees

\subsection{Diseases}

Field observations could not link the mukwa dieback symptoms to fungal or bacterial pathogens isolated. However, plants with mistletoe infestations had dieback on the distal parts of the infected branches (Figure 2). 
The dieback was however minor as compared to that associated elephant and fire damage. The fungus, Fusarium oxysporum was reportedly associated with Dieback in Zimbabwe due to relatively dry conditions existing during the sampling periods (Patterson et al., 2007). Mehl et al. (2010) reported several organisms that are associated with dieback in the P. angolensis. These included saprophytic species such as Candida, Penecillium and Humicola spp. The potentially pathogenic species included Lasiodiplodia theobromae, Cytospora spp. and Fusarium spp. (Mehl et al., 2010).

\section{Conclusion}

Dieback occurrence was highest in areas where fires and elephants occurred and the severity was lowest in areas without elephant activity. High incidences of dieback were therefore associated with increased occurrence of fires and elephants in the forest reserves. Termite activity was high with tunnelling in P. angolensis tree stems. The pest and disease connection to dieback problem could not be determined but further investigations are required to confirm these observations. The study need to be repeated in the future to compare the current damage with any future damage so that conservation and protection measured could be implemented expediently.

\section{References}

Anon, E. O. (1985). A re-assessment of effects of dieback on miombo woodland in the Zambian copper belt. Journal of Tropical Ecology, 4, 361-372.

Banda, T., Schwartz, T. M., \& Caro, T. (2006). Effects of fire on germination of Pterocarpus angolensis. Forest Ecology and Management, 233, 116-120. http://dx.doi.org/10.1016/j.foreco.2006.06.006

Ben-Shahar, R. (1993). Patterns of elephant damage to vegetation in northern Botswana. Biological Conservation, 65, 249-256. http://dx.doi.org/10.1016/0006-3207 (93)90057-8

Ben-Shahar, R. (1996). Woodland dynamics under the influence of elephants and fire in northern Botswana. Plant Ecology, 123, 153 -163. http://dx.doi.org/10.1007/BF00118268

Ben-Shahar, R. (1998). Changes in structure of the savannah woodlands in northern Botswana following the impacts of elephants and fire. Plant Ecology, 136, 189-194. http://dx.doi.org/10.1023/A:1009708021735

Bhalotra, Y. P. R. (1985). Rainfall maps of Botswana. Department of Meteorological Services. Gaborone, Botswana.

Coates Palgrave, K. (1992). Trees of Southern Africa. (2nd ed.). Struik Publisher, Cape Town. p.59.

Coetzee, S. T., \& van Vuuren, N. J. J. (1984). Characteristics and uses of South African timbers. Information leaflets. Department of Environmental Affairs, Pretoria no. 15 Pterocarpus angolensis DC.

Department of Matereological Services (2004). Weather and Agrometereology. Republic of Botswana.

Kikula, I. S. (1986). The influence of fire on the composition of the miombo woodlands of SW Tanzania. Oikos, 46, 317-324. http://dx.doi.org/10.2307/3565829

MacGregor, S. D., \& O'Connor, T. G. (2002). Patch dieback of Colophospermum mopane in dysfunctional $\begin{array}{llll}\text { semi-arid African } & \text { savannah. Austral }\end{array}$ http://dx.doi.org/10.1046/j.1442-9993.2002.01192.x

Mehl, J. W. M., Geldenhuys, C. J., Roux, J., \& Wingfield, M. J. (2010). Dieback of Kiaat (Pterocarpus angolensis) in Southern Africa: a cause for concern. Southern Forests: a Journal of Forest Science, 72, (3/4), 121-132.

Moneela, G. C., O’ Kting'ati, A., \& Kiwele, P. M. (1993). Socio-economic aspects of charcoal consumption and environmental consiquences along the Dar es Salaas-Morogoro highway, Tanzania. Forest Ecology and Management, 58, 249-258. http://dx.doi.org/10.1016/0378-1127(93)90148-G

Nowergian Forestry Society. (1992). Chobe Forest Inventory and Management Plan. Ministry of Agriculture, Gaborone, Botswana.

Patterson, W., Saint-Cyr, C. J. W., \& Russell, D. (2007). Conservation of tropical forests and biological diversity.

Rampart, M. (2007). Effects of fire and elephants on the growth of Pterocarpus angolensis (Mukwa) seedlings/ saplings in the Chobe Forest Reserves (Botswana). A dissertation submitted to the University of Wales, MSc in Environmental Forestry. School of the Environment and Natural Resources, University of Wales, Bangor. 